\title{
Complex history of a zircon aggregate from lunar breccia 73235
}

\author{
R.T. Pidgeon ${ }^{\mathrm{a}, *}$, A.A. Nemchin ${ }^{\mathrm{b}}$, W. van Bronswijk ${ }^{\mathrm{c}}$, T. Geisler ${ }^{\mathrm{d}}$, \\ C. Meyer ${ }^{\mathrm{e}}, \mathrm{W}$. Compston ${ }^{\mathrm{f}}$, I.S. Williams ${ }^{\mathrm{f}}$ \\ a Department of Applied Geology, Curtin University of Technology, Bentley, WA 6102, Australia \\ ${ }^{\mathrm{b}}$ Western Australian School of Mines, Curtin University of Technology, Bentley, WA 6102, Australia \\ ${ }^{\mathrm{c}}$ Department of Applied Chemistry, Curtin University of Technology, Bentley, WA 6102, Australia \\ ${ }^{\mathrm{d}}$ Mineralogisches Institut, Universität Münster, Correnstr. 24, 48149 Münster, Germany \\ e Astromaterials Curation KT, NASA Johnson Space Center, Houston, TX 77058, USA \\ ${ }^{\mathrm{f}}$ Research School of Earth Sciences, Australian National University, Canberra, ACT 2601, Australia
}

Received 12 May 2006; accepted in revised form 10 November 2006

\begin{abstract}
Results are reported of an investigation of the age and origin of the exceptional zircon aggregate in an anorthositic clast from lunar breccia 73235. Cathodoluminescence and birefringence images show that the aggregate consists of numerous angular fragments of sector zoned primary zircon in a matrix of secondary zircon with an overall texture that resembles a pseudotachylite. SIMS U-Pb analyses of the primary fragments and the matrix yielded two clearly defined ages, an age of $4.315 \pm 0.015 \mathrm{Ga}$ and initial Th/U ratio of $0.21-0.35$ for the primary zircon and an age of $4.187 \pm 0.011 \mathrm{Ga}$ and $\mathrm{Th} / \mathrm{U}$ of $0.04-0.17$, for the secondary zircon matrix. A Raman spectroscopic study the secondary matrix zircon was undertaken to investigate its structure. Results showed that the matrix has a zircon structure but there is also evidence for the presence of an amorphous component. Implications of the structural and U-Pb age data are discussed in terms of the origin and evolution of the aggregate and the history of lunar events. It is proposed that an original single, millimetresized, sector zoned zircon, formed at $4.31 \mathrm{Ga}$, was subjected to a severe shock event at $4.18 \mathrm{Ga}$. This event resulted in the fracturing of the zircon, the displacement and rotation of fragments, the compression of the aggregate to a lensoid shape, and the shock reduction of zircon to sub-micron-sized and amorphous granules in crush zones in the mosaic of fractures. Volatilisation loss of $\mathrm{Pb}$ and the addition of $U$ to the secondary zircon is attributed to processes activated by the extreme thermal pulse which accompanied the 4.18 Ga shock event. Shock effects are seen in some of the primary fragments but Raman spectra of the primary and secondary zircon show no evidence for pressure-induced transformation of zircon to a scheelite structure. The zircon U-Pb system has not been affected by the ca. $3.95 \mathrm{Ga}$ thermal pulse that accompanied formation of the host breccia although this event has largely reset the K-Ar systems.
\end{abstract}

(C) 2006 Elsevier Inc. All rights reserved.

\section{Introduction}

A zircon assemblage in lunar breccia 73235 was described in an extended abstract by Smith et al. (1986) as resembling a cluster of pomegranate seeds situated in a clast dominated by bytownite. They reported that highcontrast back-scattered electron (BSE) images of the zircon assemblage clearly showed an overgrowth around most of the crystals and that the overgrowth is separated from the

\footnotetext{
* Corresponding author. Fax: +61 892663153.

E-mail address: r.pidgeon@curtin.edu.au (R.T. Pidgeon).
}

interior regions by a bright "fence" which in some cases has straight lines and sharp corners indicating crystallographic control. They noted that fractures that cut across the interiors of the crystals do not appear to continue into or across the overgrowth rims. They further reported that the interior regions possessed zoning similar to sector zoning and that $\mathrm{Y}$ and $\mathrm{P}$ were depleted and $\mathrm{U}$ enriched in the rims compared to the interiors. Most significantly they found that the interiors have a SHRIMP - determined $\mathrm{U}-\mathrm{Pb}$ age of $4.31 \mathrm{Ga}$ whereas the "rims" have an age of $4.18 \mathrm{Ga}$. Smith et al. (1986) proposed that ca 4.31 billion years ago a relatively large $(500+$ micron) zircon crystallised within a clast of $\mathrm{Ca}$ rich plagioclase. The zircon was 
fractured into numerous smaller crystals and was subsequently overgrown by a second generation of zircon at approximately $4.18 \mathrm{Ga}$. The original bytownite clast was also shattered and regrown within the same time frame. Both zircon and bytownite were later emplaced within a melt sheet (breccia) around $4.0 \mathrm{Ga}$, without suffering any substantial lead loss or gain.

The complex zircon aggregate, with two distinct $\mathrm{U}-\mathrm{Pb}$ ages for different parts of the assemblage is unlike any other zircon occurrence known to the authors in terrestrial or lunar rocks. Understanding the significance of this occurrence in terms of lunar history represents a challenging problem. With this as our aim we have extended the work of Smith et al. (1986) by undertaking SHRIMP U$\mathrm{Pb}$ analyses, aimed at corroborating the two ages registered by the zircon, and by undertaking SEM cathodoluminescence, optical microscope studies, Raman spectroscopic, oxygen isotope and REE studies of the zircon aggregate. In this paper we report the total SHRIMP U-Pb data set, including the previously unpublished data described by Smith et al. (1986), and describe our imagery observations and Raman results, but do not include the oxygen isotope and REE analyses on the grounds that they do not add substantially to the interpretation. Finally we discuss the implications of our results for understanding the origin and history of the pomegranate zircon aggregate. Preliminary results have been presented by Pidgeon et al. (2005, 2006).

\section{Breccia 73235}

Lunar rock 73235 was collected during the Apollo 17 mission to the Taurus-Littrow Valley at the edge of the Serenitatis basin. 73235 is one of several samples (including 73215, 73217 and 73255) recovered from the rim of a 10 meter crater into landslide material off the South Massif (Wolf, 1981). The rock sample is a clast-rich aphanitic melt breccia with a variety of mineral and lithic clasts comprising about $75 \%$ dense matrix, $10 \%$ lithic clasts larger than a few millimetres across, and $15 \%$ mineral clasts larger than about $0.05 \mathrm{~mm}$ (Spudis and Ryder, 1981; Ryder, 1993). Lithic clasts include granoblastic feldspathic impactites with a variety of grain sizes, shocked anorthosites and cataclasized troctolites and norites. Mineral clasts exhibit a wide range of shock features (Hodges and Kushiro, 1974) and are generally rounded by resorption (Ryder, 1993). Dence et al. (1976) remarked that approximately $15 \%$ of the clasts are relatively coarsegrained, plagioclase-rich fragments with distinct evidence of shock metamorphism. Based on chemistry, Rhodes et al. (1974) classified the rock as a KREEP-like noritic breccia. Dence et al. (1976) and Wolf (1981) concluded that samples collected at the Apollo 17 Taurus-Littrow site are part of the Serenitatis basin ejecta sequence. However, Spudis and Ryder (1981) suggested that the breccia probably includes exotic components as well as reworked local material.
These rocks $(73235,73215,73217$ and 73255$)$ were not sufficiently heated to erase or completely re-equilibrate ${ }^{40} \mathrm{Ar}-{ }^{39} \mathrm{Ar}$ ages of all the older materials within them. Indeed 73215 (a sister sample to 73235) was referred to as the "rock of many ages" by Jessberger et al. (1977). These authors reported an age of $3.92 \pm 0.04 \mathrm{Ga}$ for the breccia-forming event, in agreement with the report by Turner and Cadogan (1975) of a whole rock stepwise heating ${ }^{40} \mathrm{Ar} /{ }^{39} \mathrm{Ar}$ age of $3.90 \pm 0.04 / 0.08 \mathrm{Ga}$ for our studied rock "aphanitic melt " breccia 73235 (Ryder, 1993). This result is one of a significant number of ${ }^{40} \mathrm{Ar} /{ }^{39} \mathrm{Ar}$ ages of about $4.0 \mathrm{Ga}$ for annealed or recrystallised noritic breccias from Apollo 17 (see also Kirsten and Horn, 1974), which Turner and Cadogan (1975) relate to the Serenitatis event. In addition, a number of rocks from Apollo 17 have well-defined ${ }^{40} \mathrm{Ar} /{ }^{39} \mathrm{Ar}$ ages as old as $4.3 \mathrm{Ga}$ (Jessberger et al., 1977), and Turner and Cadogan (1975) comment that, if only samples with well-developed and unambiguous age plateaux are considered, there appears to be a distinct clustering around $4.23 \pm 0.05 \mathrm{Ga}$, clearly separated from the dominant 3.9-4.0 Ga age cluster. Nyquist et al. (1974) reported $\mathrm{Rb}-\mathrm{Sr}$ whole-rock isochron ages for KREEP rich Apollo 17 noritic breccias and anorthositic gabbros of 4.02$4.09 \mathrm{Ga}$, and a $\mathrm{Rb}-\mathrm{Sr}$ whole rock isochron age of $4.02 \pm .0 .01 \mathrm{Ga}$ for Apollo 17 noritic breccias including 73235 , in broad agreement with the argon results. They also reported two stage model $\mathrm{Rb}-\mathrm{Sr}$ ages, following the formulation of Schonfeld and Myer (1972), of 4.46 and $4.30 \mathrm{Ga}$ for two Apollo 17 noritic breccias and also whole-rock isochron ages ranging from 4.19 to $4.34 \mathrm{Ga}$ for selected combinations of chemically defined rock types from Apollo17 and Apollo 16 samples.

In this paper we are concerned with a single unique clast in breccia 73235 found in thin section (82) (Fig. 1A and B). This consists of an aggregate of approximately 75 broken fragments of zircon included in a polygonal patch of about 25 plagioclase crystals. The rounded plagioclase clast is eroded around the margin (Fig. 1A and B) and appears to have reacted with the surrounding matrix.

\section{The zircon aggregate "pomegranate"}

The irregular outline of the zircon occurrence, in the plane of the thin section, is shown in the BSE image in Fig. 1A. From the CL image of the same area it can be seen that the zircon forms an aggregate of irregular shaped fragments with a range of sizes and variable $\mathrm{CL}$ intensities (Fig. 1B). The angular shapes and varied grain size of fragments is also evident in the birefringent image of part of the aggregate shown on Fig. 7 Examination of the CL patterns of the larger of the individual zircon grains (Fig. 2) shows that the grains are divided internally into sectors, each with a different but uniform CL intensity, separated from one another by straight-line boundaries. Assuming that 

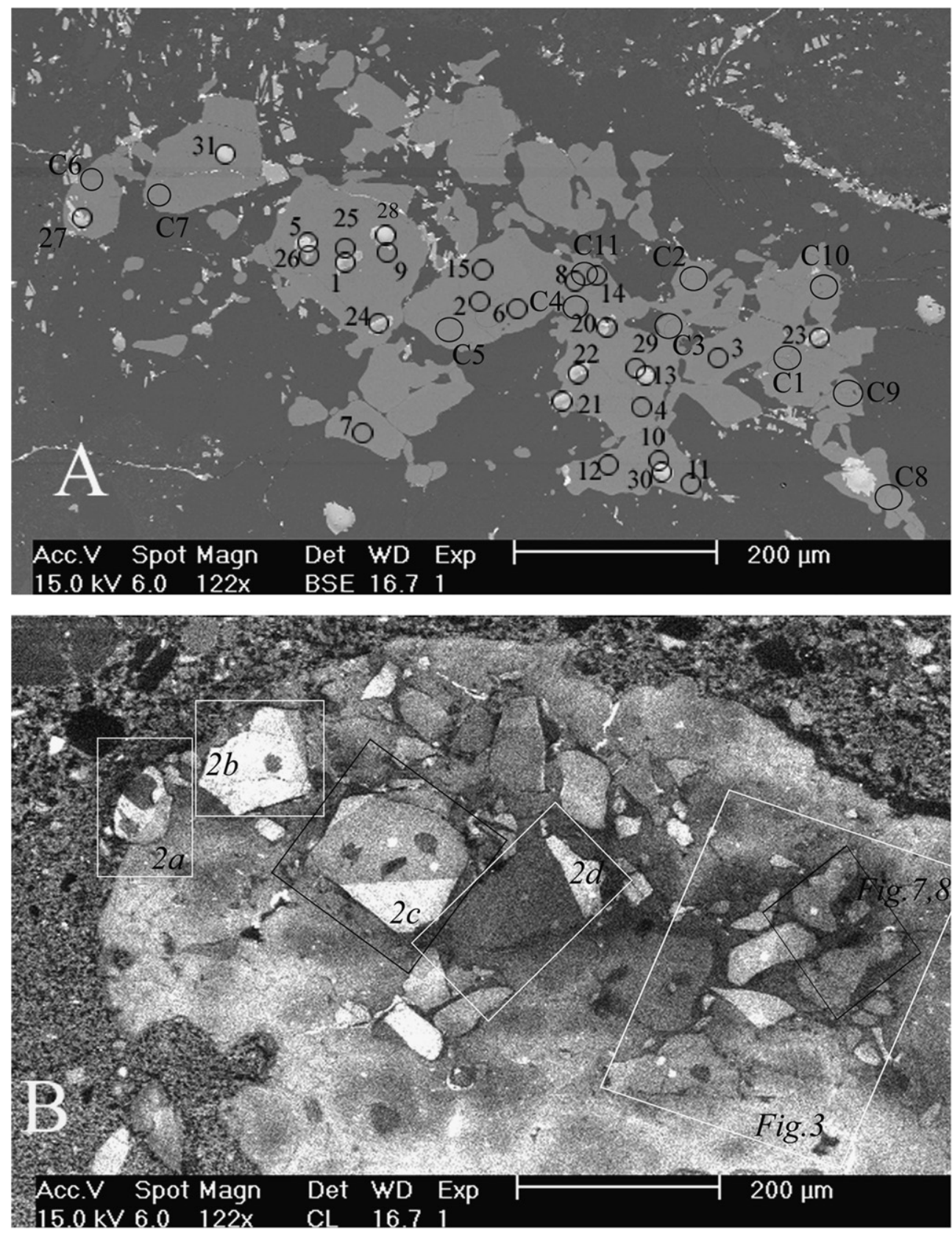

Fig. 1. (A) Low contrast backscattered electron (BSE) image showing the irregular shape of the zircon aggregate (light grey). Numbered circles show location of SHRIMP analyses (Table 1) made at the Australian National University and the Curtin University of Technology (C). (B) A cathodoluminescence (CL) image of the same area shows the rounded outline of the light grey CL, plagioclase-bearing host "clast" and the fragmented texture of the zircon aggregate. Rectangular outlines refer to locations shown in subsequent figures, as indicated by the numbers.

originally the zircon aggregate consisted of one grain with a regular patterns of sector zoning, it can be seen in Figs. 1 and 3 that zone boundaries cannot be traced from one fragment to another demonstrating that the primary zircon fragments have been displaced and rotated.

The CL image shows that angular fragments and shards of primary zircon are set in a matrix of dark CL material (Fig. 3b). SEM X-ray imaging of the distribution of $\mathrm{Zr}$ and $\mathrm{Si}$ (not shown), together with the presence of $\mathrm{Zr}$ mass peaks in our SHRIMP runs and Raman measurements de- scribed below confirm conclusions by Smith et al. (1986) that the matrix material is zircon. The zircon fragments are irregular in size and shape and the overall structure of the aggregate is that of displaced angular fragments set in a dark CL "cement", resembling that of a pseudotachylite (Fig. 3). The external form and elongate shape of the aggregate suggests that originally it consisted of a single large crystal that has been shattered compressed and extended under transitional stress during impact.

Macroscopic shock features are not immediately evident in the zircon aggregate. However, Smith et al. (1986) inter- 

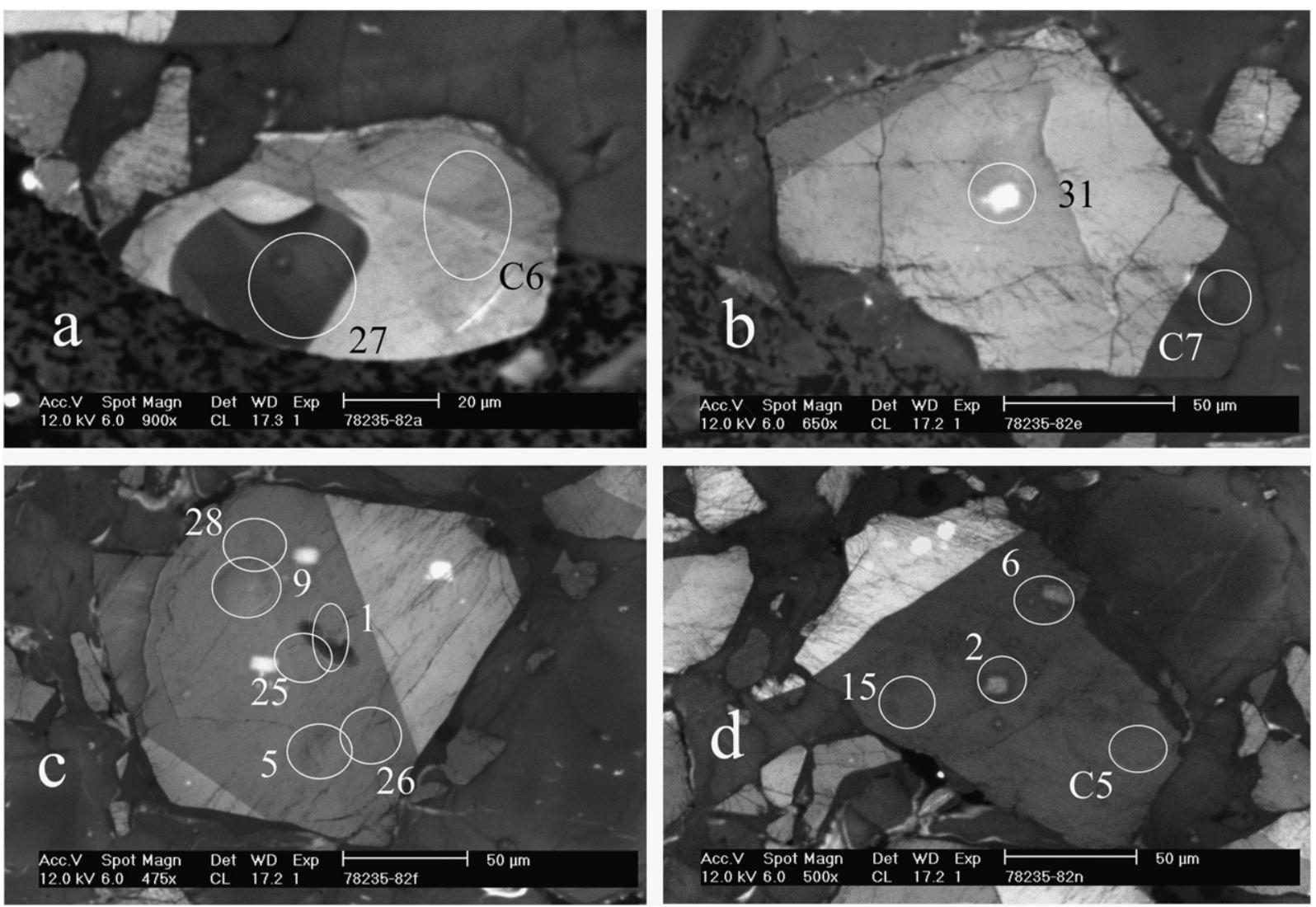

Fig. 2. CL images showing sector zoning patterns in four of the largest zircon fragments. (a) This fragment is situated on the outside of the anorthositic clast and its rounded surface is attributed to mechanical abrasion during formation of the breccia. It consists of light-grey CL,wedge-shaped sectors and a rounded, dark CL patch. (b-d) These fragments consist of dark-grey CL segments separated by straight-line borders from adjacent segments of lighter CL zircon. Fine sub-parallel hair-line fractures are evident in the fragments.

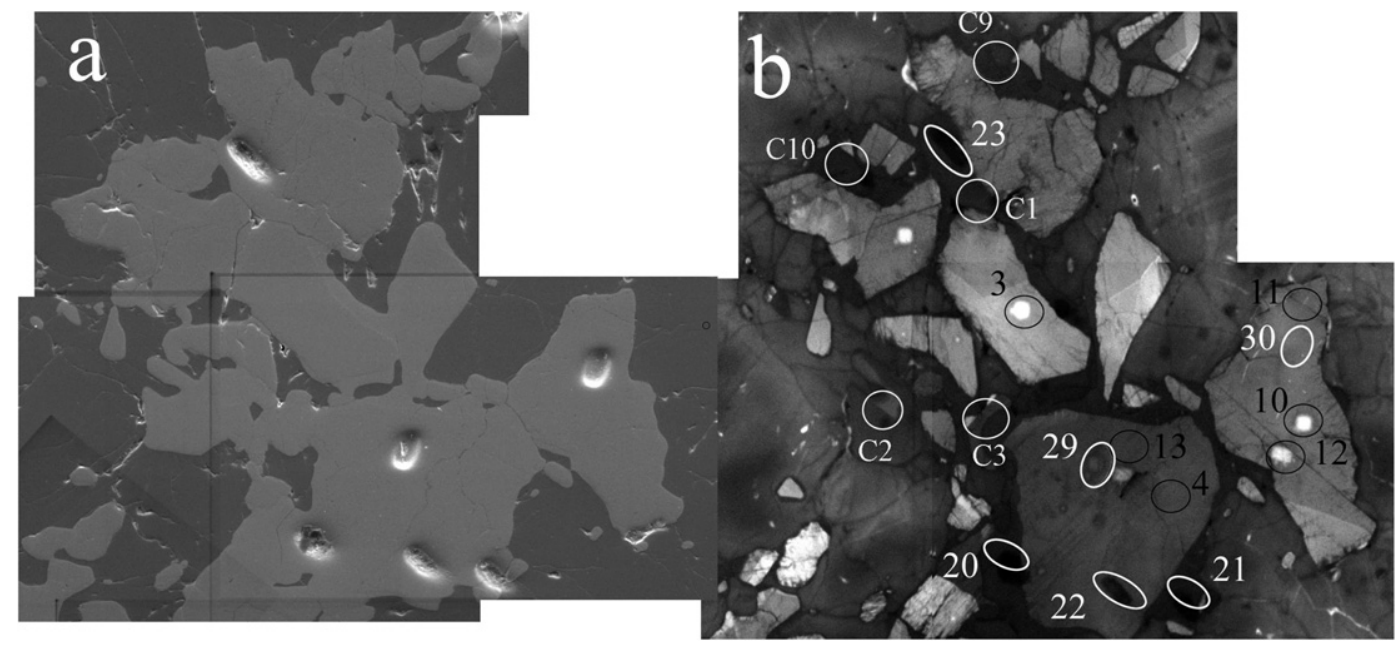

Fig. 3. (a) Secondary electron (SE) image of part of the zircon aggregate. (b) A CL image of the same area shown in (a). Numbered white and black circles refer to SHRIMP analytical spots (Table 1). The CL image reveals the structure of the aggregate as an array of irregular shaped fragments of primary zircon contained within a matrix of secondary zircon. The displacement of sector zones seen in adjacent fragments demonstrates the relative movement of the fragments.

preted fine fractures in the zircon fragments as shock features and implied that they preceded formation of the matrix zircon. We also observe fine, sub-parallel fractures in individual fragments (e.g., Fig. 2a) and sets of closely spaced fine parallel lines in the birefringent images of some fragments (Fig. 7), that are approximately coincident with the sub-parallel fractures and are interpreted as planar deformation features (PDF). 


\section{Analytical techniques}

\subsection{SIMS geochronology}

The present study combines the results of SHRIMP 1 $\mathrm{U}-\mathrm{Pb}$ measurements made at the Research School of Earth Sciences at the Australian National University (ANU) in the 1980s with SHRIMP II measurements undertaken at Curtin University in 2003. The ANU results form part of an early geochronological program on lunar zircons undertaken on SHRIMP1 using methods described in detail by Compston et al. (1984). The analytical techniques were also described by Meyer et al. (1996) and we refer to these reports for a detailed description of the methods and the analytical precision, which is reflected in the uncertainties in isotope ratios and ages presented in Table 1. It is beyond the scope of this contribution to discuss the performances of the SHRIMP I and SHRIMP II instruments or the extensive work on standards which is described in the above references. However, early studies at the ANU identified a bias in the $\mathrm{Pb} / \mathrm{U}$ ratio between the standard and the unknown zircon where these were contained in two separate mounts in the source chamber and analysed by moving the mounts alternatively under the primary beam. The problem was overcome by inserting a $2 \mathrm{~mm}$ resin plug containing chips of the standard into a hole in the sample mount thereby making the ion extraction geometry as close as possible for the standard and unknown (Meyer et al., 1996). The ANU data presented in Table 1 were accumulated over a number of years and have been recalculated by ISW and WC to account for all early sources of error. In these calculations an important issue is the correction for initial $\mathrm{Pb}$. Direct SHRIMP measurements show that lunar "common $\mathrm{Pb}$ " in a felsite clast from breccia 14163 is extremely radiogenic (Compston et al., 1991) and has a significant effect on $\mathrm{U}-\mathrm{Pb}$ calculations if not accounted for

Table 1

SHRIMP analytical data

\begin{tabular}{|c|c|c|c|c|c|c|c|c|c|c|c|c|c|c|}
\hline Spot & $\mathrm{U}(\mathrm{ppm})$ & Th (ppm) & $\frac{\mathrm{Th}}{\mathrm{U}}$ & ${ }^{204} \mathrm{~Pb}$ & $\frac{{ }^{207} \mathrm{~Pb}^{*}}{{ }^{235} \mathrm{U}}$ & $\pm 1 \sigma$ & $\frac{{ }^{206} \mathrm{~Pb}^{*}}{{ }^{238} \mathrm{U}}$ & $\pm 1 \sigma$ & $\begin{array}{l}{ }^{207} \mathrm{~Pb}^{*} \\
{ }^{206} \mathrm{~Pb}^{*}\end{array}$ & $\pm 1 \sigma$ & $\frac{{ }^{206} \mathrm{~Pb}^{*}}{{ }^{238} \mathrm{U}}$ Age $(\mathrm{Ma})$ & $\pm 1 \sigma$ & ${ }^{207} \mathrm{~Pb}^{*} \mathrm{~Pb}^{*}$ Age $(\mathrm{Ma})$ & $\pm 1 \sigma$ \\
\hline \multicolumn{15}{|c|}{$A N U$} \\
\hline 1 & 25 & 14 & 0.56 & 0.001484 & 65.3 & 1.8 & 0.898 & 0.022 & 0.5286 & 0.0050 & 4130 & 75 & 4320 & 14 \\
\hline 2 & 61 & 35 & 0.57 & 0.000695 & 67.8 & 1.5 & 0.958 & 0.020 & 0.5134 & 0.0030 & 4332 & 65 & 4280 & 9 \\
\hline 4 & 54 & 31 & 0.57 & 0.000652 & 68.2 & 1.5 & 0.941 & 0.020 & 0.5256 & 0.0033 & 4274 & 64 & 4315 & 9 \\
\hline 5 & 24 & 12 & 0.50 & 0.001307 & 66.0 & 1.9 & 0.931 & 0.023 & 0.5144 & 0.0050 & 4242 & 78 & 4283 & 14 \\
\hline 6 & 77 & 32 & 0.42 & 0.000449 & 63.5 & 1.3 & 0.913 & 0.018 & 0.5045 & 0.0025 & 4181 & 60 & 4254 & 7 \\
\hline 7 & 18 & 8 & 0.44 & 0.001218 & 63.7 & 2.0 & 0.891 & 0.024 & 0.5184 & 0.0057 & 4105 & 82 & 4294 & 16 \\
\hline 8 & 171 & 27 & 0.16 & 0.000203 & 56.3 & 1.0 & 0.858 & 0.015 & 0.4760 & 0.0018 & 3995 & 52 & 4169 & 6 \\
\hline 9 & 27 & 15 & 0.56 & 0.001250 & 63.3 & 1.4 & 0.870 & 0.018 & 0.5278 & 0.0040 & 4034 & 60 & 4321 & 11 \\
\hline 10 & 30 & 21 & 0.70 & 0.000539 & 71.4 & 1.5 & 0.985 & 0.019 & 0.5259 & 0.0035 & 4418 & 62 & 4316 & 10 \\
\hline 11 & 36 & 25 & 0.69 & 0.000651 & 59.8 & 1.3 & 0.840 & 0.017 & 0.5165 & 0.0037 & 3930 & 58 & 4289 & 11 \\
\hline 13 & 57 & 32 & 0.56 & 0.000704 & 72.3 & 1.8 & 1.000 & 0.023 & 0.5242 & 0.0044 & 4467 & 74 & 4311 & 12 \\
\hline 14 & 47 & 21 & 0.45 & 0.000623 & 64.9 & 1.8 & 0.934 & 0.023 & 0.5039 & 0.0057 & 4251 & 76 & 4253 & 17 \\
\hline 15 & 62 & 36 & 0.58 & 0.000878 & 71.4 & 1.9 & 0.971 & 0.023 & 0.5337 & 0.0046 & 4374 & 75 & 4337 & 13 \\
\hline 20 & 166 & 29 & 0.17 & 0.000479 & 54.2 & 1.0 & 0.809 & 0.014 & 0.4861 & 0.0017 & 3822 & 50 & 4200 & 5 \\
\hline 21 & 178 & 28 & 0.16 & 0.000225 & 53.3 & 1.0 & 0.808 & 0.014 & 0.4785 & 0.0018 & 3818 & 50 & 4176 & 6 \\
\hline 22 & 56 & 31 & 0.55 & 0.000952 & 62.5 & 1.2 & 0.860 & 0.016 & 0.5275 & 0.0030 & 4000 & 56 & 4320 & 8 \\
\hline 23 & 215 & 22 & 0.10 & 0.000247 & 53.2 & 0.9 & 0.804 & 0.014 & 0.4801 & 0.0013 & 3802 & 49 & 4181 & 4 \\
\hline 24 & 92 & 15 & 0.16 & 0.000552 & 54.9 & 1.0 & 0.818 & 0.015 & 0.4867 & 0.0020 & 3852 & 52 & 4201 & 6 \\
\hline 25 & 23 & 12 & 0.52 & 0.002331 & 61.8 & 1.5 & 0.858 & 0.019 & 0.5225 & 0.0047 & 3993 & 65 & 4306 & 13 \\
\hline 26 & 25 & 14 & 0.56 & 0.000956 & 69.8 & 1.8 & 0.970 & 0.024 & 0.5215 & 0.0033 & 4372 & 78 & 4303 & 9 \\
\hline 27 & 15 & 6 & 0.40 & 0.001263 & 68.8 & 1.9 & 0.949 & 0.025 & 0.5261 & 0.0041 & 4301 & 83 & 4316 & 11 \\
\hline 28 & 24 & 13 & 0.54 & 0.000673 & 68.9 & 1.8 & 0.975 & 0.024 & 0.5126 & 0.0033 & 4386 & 78 & 4278 & 9 \\
\hline 29 & 61 & 33 & 0.54 & 0.000221 & 69.6 & 1.6 & 0.943 & 0.021 & 0.5349 & 0.0021 & 4283 & 68 & 4340 & 6 \\
\hline 30 & 354 & 24 & 0.07 & 0.000317 & 72.8 & 1.8 & 0.995 & 0.023 & 0.5304 & 0.0029 & 4453 & 75 & 4328 & 8 \\
\hline 31 & 14 & 6 & 0.43 & 0.001772 & 68.2 & 2.0 & 0.946 & 0.026 & 0.5231 & 0.0043 & 4290 & 86 & 4308 & 12 \\
\hline \multicolumn{15}{|c|}{ Curtin } \\
\hline $\mathrm{C} 1$ & 86 & 23 & 0.27 & 0.000080 & 64.1 & 1.7 & 0.962 & 0.025 & 0.4837 & 0.0019 & 4344 & 83 & 4192 & 6 \\
\hline $\mathrm{C} 2$ & 106 & 52 & 0.51 & 0.000083 & 74.7 & 1.9 & 1.007 & 0.025 & 0.5377 & 0.0021 & 4491 & 83 & 4349 & 5 \\
\hline C3 & 124 & 27 & 0.22 & 0.000035 & 62.0 & 1.5 & 0.926 & 0.023 & 0.4860 & 0.0019 & 4223 & 78 & 4199 & 5 \\
\hline $\mathrm{C} 4$ & 94 & 18 & 0.19 & 0.000041 & 54.7 & 1.4 & 0.830 & 0.021 & 0.4780 & 0.0024 & 3895 & 74 & 4175 & 7 \\
\hline $\mathrm{C} 5$ & 52 & 27 & 0.53 & 0.000010 & 70.2 & 1.9 & 0.973 & 0.024 & 0.5232 & 0.0031 & 4382 & 86 & 4308 & 8 \\
\hline C6 & 65 & 29 & 0.45 & 0.000028 & 72.0 & 1.9 & 1.000 & 0.026 & 0.5222 & 0.0031 & 4468 & 85 & 4305 & 8 \\
\hline C7 & 62 & 32 & 0.52 & 0.000052 & 69.7 & 1.9 & 0.965 & 0.026 & 0.5244 & 0.0026 & 4353 & 84 & 4311 & 7 \\
\hline $\mathrm{C} 8$ & 113 & 29 & 0.27 & 0.000042 & 62.3 & 1.6 & 0.927 & 0.023 & 0.4873 & 0.0019 & 4227 & 79 & 4203 & 6 \\
\hline C9 & 113 & 18 & 0.17 & 0.000053 & 63.5 & 1.6 & 0.953 & 0.023 & 0.4833 & 0.0019 & 4314 & 80 & 4191 & 5 \\
\hline $\mathrm{C} 10$ & 147 & 24 & 0.17 & 0.000038 & 63.3 & 1.6 & 0.955 & 0.024 & 0.4811 & 0.0014 & 4321 & 79 & 4184 & 5 \\
\hline C11 & 131 & 21 & 0.17 & 0.000011 & 61.8 & 1.5 & 0.939 & 0.023 & 0.4775 & 0.0014 & 4268 & 79 & 4173 & 5 \\
\hline
\end{tabular}

Radiogenic. 
correctly. Meyer et al. (1996) reported that the initial $\mathrm{Pb}$ was thought to be dominantly $\mathrm{Pb}$ from lunar or meteorite sources that had been smeared over the polished surface of the zircons during polishing, rather than contaminant $\mathrm{Pb}$ from the laboratory materials. The common $\mathrm{Pb}$ correction for the ANU data was calculated by assuming a mixture of lunar initial $\mathrm{Pb}$ and meteoritic $\mathrm{Pb}$ similar to that in Canyon Diablo troilite and a closed $\mathrm{Th}-\mathrm{Pb}$ system.

The analytical procedures for the Curtin consortium SHRIMP II have been described by De Laeter and Kennedy (1998); Kennedy and de Laeter (1994) and Nelson (1997) and are similar to those described by Compston et al. (1984) and Williams (1988). A slightly radiation damaged Sri Lankan gem zircon was used as the standard (Pidgeon et al., 1994) and both laboratories calculated results with decay constants recommended by Steiger and Jäger (1977). Curtin procedures differed from those at the ANU in two ways. Firstly, analyses on the Curtin SHRIMP were made with the sample and the standard in separate mounts in the source and analysed by switching mounts at regular intervals. Tests on the standard did not identify any bias in measuring grains in alternate mounts and we have not observed any systematic bias that would cause us to abandon this measurement procedure. Secondly, the amount of common $\mathrm{Pb}$ in our lunar zircons, as indicated by ${ }^{204} \mathrm{~Pb}$, was found to be extremely low and was attributed to contamination during sample polishing and gold coating and a Broken Hill $\mathrm{Pb}$ isotopic composition was assumed for the correction. Calculations of radiogenic $\mathrm{Pb}$ in all zircons, including those in low $\mathrm{U}-\mathrm{Th}$ sectors show no age differences that can be attributed to a wrong common $\mathrm{Pb}$ composition, but the uncertainties in radiogenic $\mathrm{Pb}$ would be greater if the initial radiogenic model is used. The authors are divided on the nature of the higher common $\mathrm{Pb}$ reported in the early ANU results (Table 1), but despite these differences in data reduction, the combined results from the two laboratories, presented in Table 1 and shown on a Concordia plot in Fig. 4, are entirely consistent.

\subsection{Raman spectroscopy}

Laser-Raman spectra were obtained with an ISA LabRam dispersive Raman spectrometer using the $632.187 \mathrm{~nm}$ line of a He-Ne laser. The scattered Raman light was analysed with a charge-coupled device detector after being dispersed by a grating of 1800 grooves per $\mathrm{mm}$. A $100 \times$ objective was used on a BX-40 microscope. The spectral resolution was $2.5 \mathrm{~cm}^{-1}$. A confocal hole of $300 \mu \mathrm{m}$ was used and the lateral resolution was about $1-2 \mu \mathrm{m}$. The frequency was calibrated by measuring the $520.7 \mathrm{~cm}^{-1}$ band of silicon and the spectral lines of a $\mathrm{Ne}$ lamp before and after the sample measurements. The effect of the finite slit width on the measured linewidth given as the full width at half maximum (FWHM) was corrected by the method of Tanabe and Hiraishi (1980).

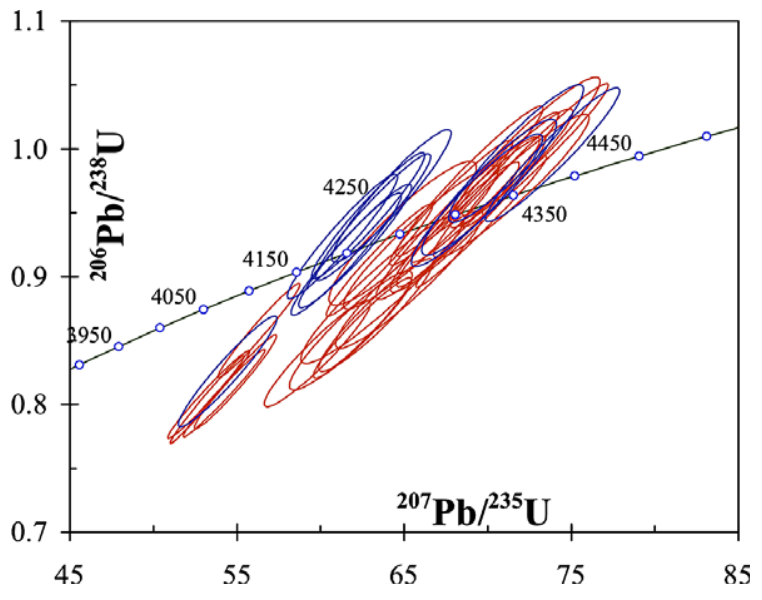

Fig. 4. Concordia plot showing SHRIMP data for the primary $(4.31 \mathrm{Ga})$ and secondary $(4.18 \mathrm{Ga})$ zircon made at the Curtin University of Technology (blue, or dark grey) and at the Australian National University (red, or light grey). Error ellipses are $2 \sigma$.

\subsection{Cathodoluminescence ( $C L)$ and secondary electron (SE) imaging}

CL, BSE and SE imaging were performed on a Philips XL30 scanning electron microscope, equipped with a K.E. Developments Limited CCD-Si cathodoluminescence detector, managed by the Curtin University Centre for Materials Research. The acceleration voltage was $15 \mathrm{keV}$ and other parameters were adjusted to maximise the intensity contrast of the CL images. The low resolution SE image (Fig. 1) was made at a non optimal CL working distance. Element maps (not reported here) of $\mathrm{Zi}, \mathrm{Al}, \mathrm{Si}$, $\mathrm{Ca}$ and $\mathrm{Fe}$, determined by mapping using the energy dispersion X-ray spectrometer, were used to confirm the area of exposed zircon identified from the BSE and SE imagery.

\section{SIMS U-Pb measurements}

Curtin SHRIMP II and the ANU SHRIMP I U-Pb measurements on the zircon aggregate are reported in Table 1. The 31 ANU measurements show a consistent concordant age of ca $4.31 \mathrm{Ga}$ for the sector-zoned zircon and a younger age of ca $4.18 \mathrm{Ga}$ for the transgressive dark CL, matrix zircon (Smith et al., 1986). However, the five ANU analyses of secondary matrix zircon are slightly discordant and it is possible to interpret the ca $4.18 \mathrm{Ga}$ age as the result of a younger disturbance of the $4.31 \mathrm{Ga}$ zircon. To resolve this question a further 11 measurements were made using the Curtin SHRIMP II concentrating on the dark CL matrix zircon (8 measurements). The resulting data are shown on a concordia plot in Fig. 4. The $1 \sigma$ data ellipses form two distinct elongate age groups which correspond with the position of the analytical spots on primary or secondary zircon. Age ellipses from primary zircon fragments distribute around ca $4.31 \mathrm{Ga}$ on concordia whereas matrix zircon ellipses concentrate at ca $4.18 \mathrm{Ga}$ (Fig. 4). The apparent discordant and reverse discordant trend is 
small to non-existent at the $2 \sigma$ level but it is possible that a very small discordance is present. This could be explained by long term radon leakage enhanced as radiation damage accumulates, but any effect is small and is not discussed further. However, there is a transition of data ellipses along concordia between the two main groups, which we attribute to mixing by analytical overlap of primary and secondary zircon. The SHRIMP spot sizes over the various analytical sessions are in the order of $20-25 \mu \mathrm{m}$ in diameter and it is shown later that the matrix zircon encloses small fragments, down to submicron size, of primary zircon. Possibly the best estimate of the age of the primary zircon is given by the weighted mean of ${ }^{207} \mathrm{~Pb} /{ }^{206} \mathrm{~Pb}$ ages from three primary sectors (Fig. 3, analyses-10,11,30: 4,13,22,29 and Fig. 1 analyses $1,5,9,25,26,28)$ of $4.315 \pm 0.015 \mathrm{Ma}(95 \%)$, which also corresponds with the median. The weighted mean of ${ }^{207} \mathrm{~Pb} /{ }^{206} \mathrm{~Pb}$ ages of Curtin measurements on the secondary zircon is $4.187 \pm 0.011 \mathrm{Ma} \quad(95 \%)$ (median $4.192 \pm 0.010 / 20 \mathrm{Ma}$ ). These ages are not significantly different from those presented by Smith et al. (1986) and in this paper we have followed Smith et al. (1986) and refer to the ages of the primary and secondary zircon as ca 4.31 and ca $4.18 \mathrm{Ga}$, respectively. The consistency of the data set is worth emphasising given the analyses were made on two different SIMS instruments (SHRIMP I and SHRIMP II) nearly 20 years apart. It is also significant that two distinct ages recording two events in the history of the zircon should be recorded in the one zircon occurrence. The uniformity of the $\mathrm{U}$ and Th concentration in individual sector zones is demonstrated by six SHRIMP measurements on the polished surface of the central dark grey sector of the grain shown in Fig. 2c which are within the narrow range of 23-27 ppm (U) and 12-15 ppm (Th) (Table 1). Four analyses on the darker-CL sector in the grain shown in Fig. 2d, fall within the wider range of 52-77 ppm $\mathrm{U}$ and $32-36 \mathrm{ppm}$ Th. The linear correlation of data points on a plot of $\mathrm{U}$ versus $\mathrm{Th}$ for the sector zoned zircon, with a slope of 0.27 (Fig. 5a), suggests the zoned zircon represents primary growth in a magma with a uniform $\mathrm{Th} / \mathrm{U}$ ratio. On the other hand U-Th data-points for the younger, transgressive, dark CL zircon matrix fall in a scattered pattern to the right of the primary zircon linear trend. This secondary zircon has a similar Th content to the primary zircon (Table 1) but a distinctly higher and non systematic content of $U$ (Fig. 5a). The difference in $U$ and $T h$ between the two zircon forms is also shown in the plot of $\mathrm{Th} / \mathrm{U}$ ratios versus age in Fig. 5b. These data support the observation of Smith et al. (1986) that $\mathrm{U}$ has been added to the secondary zircon during formation at $4.18 \mathrm{Ga}$. Analysis 30 in Table 1, is anomalous in having a primary zircon ${ }^{207} \mathrm{~Pb} /{ }^{206} \mathrm{~Pb}$ age of $4.31 \mathrm{Ga}$ and a secondary zircon $\mathrm{Th} / \mathrm{U}$ ratio of 0.10 and the highest $U$ content of all the measurements. This analysis spot was targeted as matrix zircon but behaves as if it retained its radiogenic $\mathrm{Pb}$ and has an enhanced $\mathrm{U}$.

Ireland and Wlozka (1992) reported a single SHRIMP REE analysis for the pomegranate zircon that shows strong fractionation, with a $\mathrm{Lu} / \mathrm{La}$ ratio of 3000 , a strong
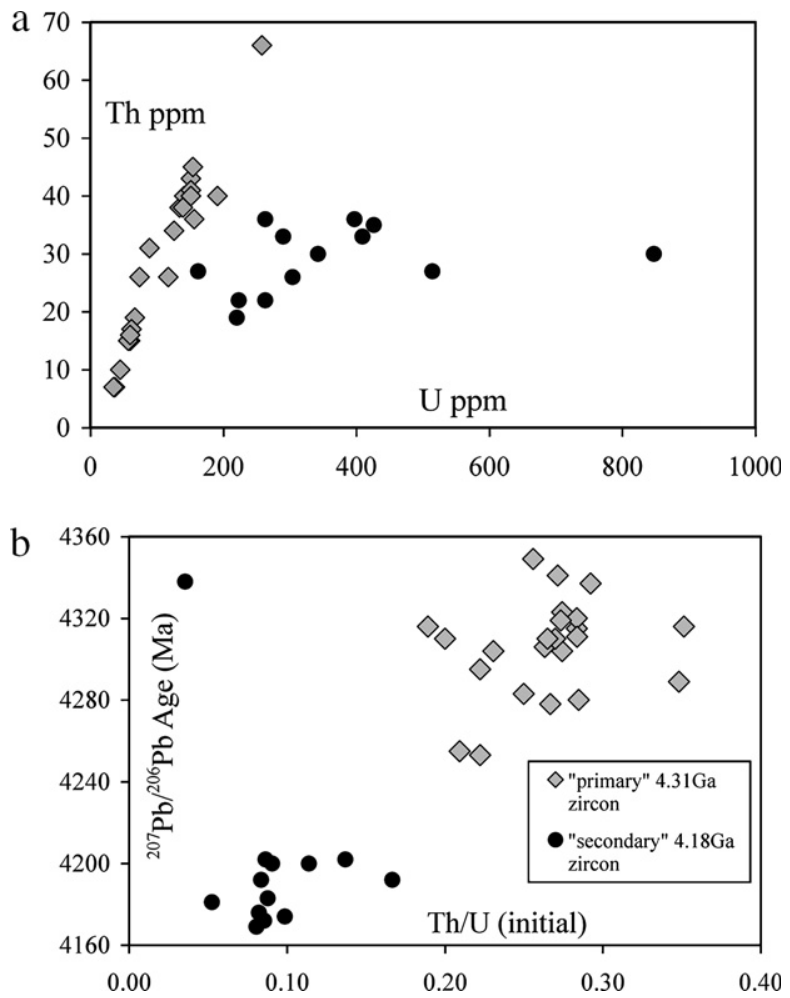

Fig. 5. Plot of $U$ and $T h$ concentrations (a), and $U / T h$ ratios plotted against age (b) for the primary and secondary zircon.

negative $\mathrm{Eu}$ anomaly and a small positive $\mathrm{Ce}$ anomaly. Their analysis spot overlapped primary and secondary zircon. Our SHRIMP REE analyses of the aggregate, to be published subsequently, generally confirm the result of Ireland and Wlozka (1992) and suggest that the fractionated REE pattern is a primary feature of the zircon.

Oxygen isotope analyses on the pomegranate zircon aggregate made on the CAMECA IMS1270 ion microprobe of the NordSIMS facility at the Swedish Museum of Natural History will also be published elsewhere. The five analyses on the primary zircon and one located on secondary zircon have $\delta^{18} \mathrm{O}$ values within the range of $5.8 \pm 0.3 \%(1 \sigma)$ which is interpreted as the oxygen isotopic composition of the primary zircon at $4.31 \mathrm{Ga}$, which does not appear to have been altered in the secondary zircon.

\section{Raman measurements and cathodoluminescence and birefringence imagery of the primary and secondary zircon}

We have undertaken a Raman study to investigate the effects of shock in the formation of the zircon aggregate. The great advantage of the Raman technique is that the structural state of a few cubic microns can be determined for selected areas of the primary and secondary zircon (Nasdala et al., 1995). Information is obtained by examining the total spectrum and also by monitoring the intensity, width (Full Width at Half Maximum) and frequency shift of the antisymmetric stretching band of the $\mathrm{SiO}_{4}$ tetrahedra located near $1008 \mathrm{~cm}^{-1}$ in crystalline zircon. The zircon lattice is known to be affected by shock (e.g., Gucsik et al., 
2002). However, Raman spectra made on homogeneous sectors of primary fragments (spectra A and B) and on secondary matrix zircon (spectrum C) (Fig. 6) show a normal zircon crystal structure with no evidence of anomalous zircon or reidite peaks (Knittle and Williams, 1993; Van Westrenen et al., 2004, 2005; Wittmann et al., 2006) and no evidence in support of a transition of matrix zircon to an amorphous state (no Raman zircon peaks) as a result of extreme shock (Gucsik et al., 2002).

To examine the matrix zircon in more detail a map of the intensity of the $v_{3}\left(\mathrm{SiO}_{4}\right)$ band, made over a small part of the aggregate shown in the SE and CL images (Fig. 8a and b), is presented in Fig. 8c. The Raman intensity map shows that a large proportion of the matrix has a zircon structure, although a lower signal intensity than the primary zircon fragments. The map also shows that the Raman intensity within the matrix zircon is inhomogeneous. For example the intensity near the boundary at the top left of Fig. 8c, between matrix zircon and surrounding minerals of the anorthosite clast, is highly irregular and indefinite, suggesting that numerous small patches of matrix zircon at and near this boundary consist largely of amorphous domains. This pattern is also observed in the birefringence image (Fig. 7) where this area consists of numerous small irregular shaped grey to yellow birefringent fragments in a black background.

However, careful examination of the images in Fig. 8 shows that, in detail, the $\mathrm{Cl}$ image, the Raman maps and the birefringent images (Fig. 7) do not provide the same information. In the inset area, for example, the birefringence image shows much narrower zones of secondary zircon than indicated in the CL image. The extra width observed in the CL image could represent a thin veneer of secondary matrix overlying deeper primary zircon that is revealed by the depth of field of the birefringent image compared with the surface record of the CL image. Also,

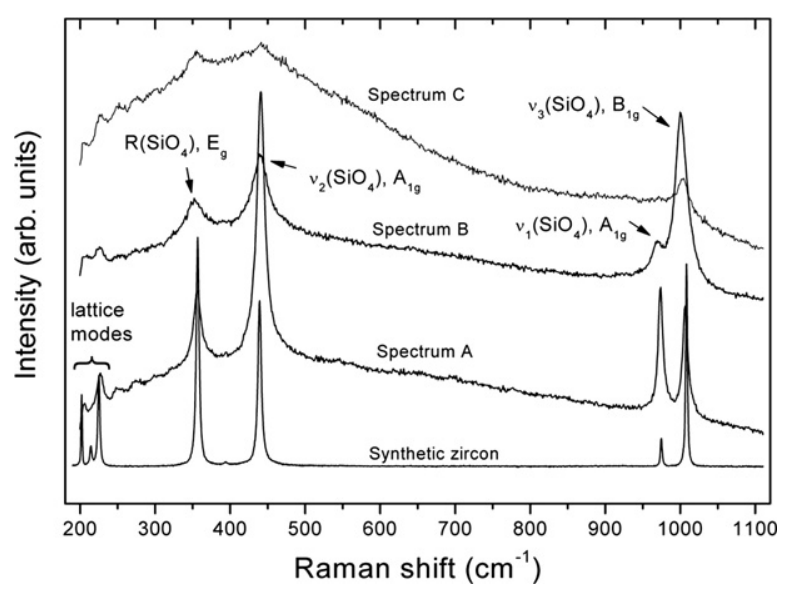

Fig. 6. Representative Raman spectra of the primary and secondary zircon. Spectrum A was taken from the large dark-grey sector in Fig. 2a, spectrum $B$ from a more radiation damaged sector in Fig. $2 b$ and spectrum $\mathrm{C}$ was taken from the matrix zircon. The synthetic zircon spectrum was taken from a single, flux-grown, synthetic zircon.

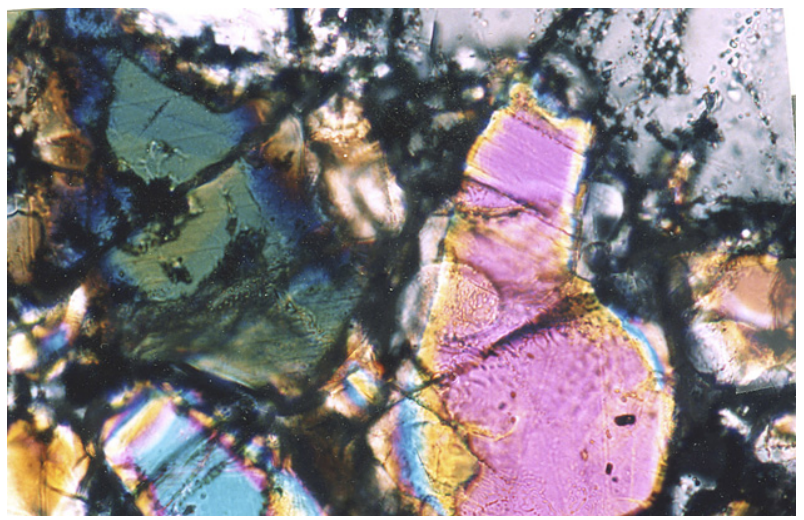

Fig. 7. Crossed polar birefringence image of the same area of the zircon aggregate as shown as a CL image in Fig. 8b and a Raman intensity image in Fig. 8c. The multiple, fine, parallel lines on the pink-birefringent grain are interpreted as shock-formed parallel deformation features.

the Raman intensity image (Fig. 8c) of the same area is, in detail, not identical to the CL or the birefringent images. For example, the right side of the $\mathrm{CL}$ image in Fig. $8 \mathrm{~b}$ (see arrow) shows a broad area of matrix zircon enclosing angular fragments of primary zircon. The pattern of Raman intensity on the same area (Fig. 8c) shows that the matrix consists of weakly crystalline zircon with a central zone of zero intensity (black). In the crossed-polar image (Fig. 7) this central black channel is evident but merges laterally into "primary" birefringent zircon which is not present in the CL image which still registers this part of the image as secondary matrix zircon. Elsewhere the matrix zircon has a mottled birefringence, varying from white to grey, suggesting a granular structure with inhomogeneous distribution of defect-rich areas, resulting from self-irradiation damage and/or from shock. These differences in the observed patterns of primary and secondary zircon from the CL, Raman intensity and crossed polar optical microscopy images are attributed in part to differences in the sampling volumes of the techniques. The SHRIMP analysis samples to a depth of about $1-2 \mu \mathrm{m}$ over a diameter of $15-20 \mu \mathrm{m}$. The SE and the CL images essentially record the near surface structure $(5-50 \mathrm{~nm})$. The Raman measurement appears to respond to a greater depth than the CL signal and the transmitted birefringent image appears to register a slightly deeper level of information than the Raman measurement. Also, some areas in the Raman contour maps exhibit essentially zero intensity although the Raman laser beam has hit zircon, possibly as a result of fluorescence or stray light obscuring the zircon signal.

A map of the peak width (FWHM) of the $v_{3}\left(\mathrm{SiO}_{4}\right)$ band (within the area of the square shown in Fig. 8a-c) is included as Fig. 8d. It can be seen from this figure that the darkCL matrix zircon (see box in Fig. 8b) is characterized by a width, between about 15 and $18 \mathrm{~cm}^{-1}$, which compares with a width below about $13 \mathrm{~cm}^{-1}$ for the primary zircon. However, the boundary between the matrix and primary zircon is irregular (Fig. 8d) and not directly comparable with the intensity map in Fig. 8c. The automatic peak 

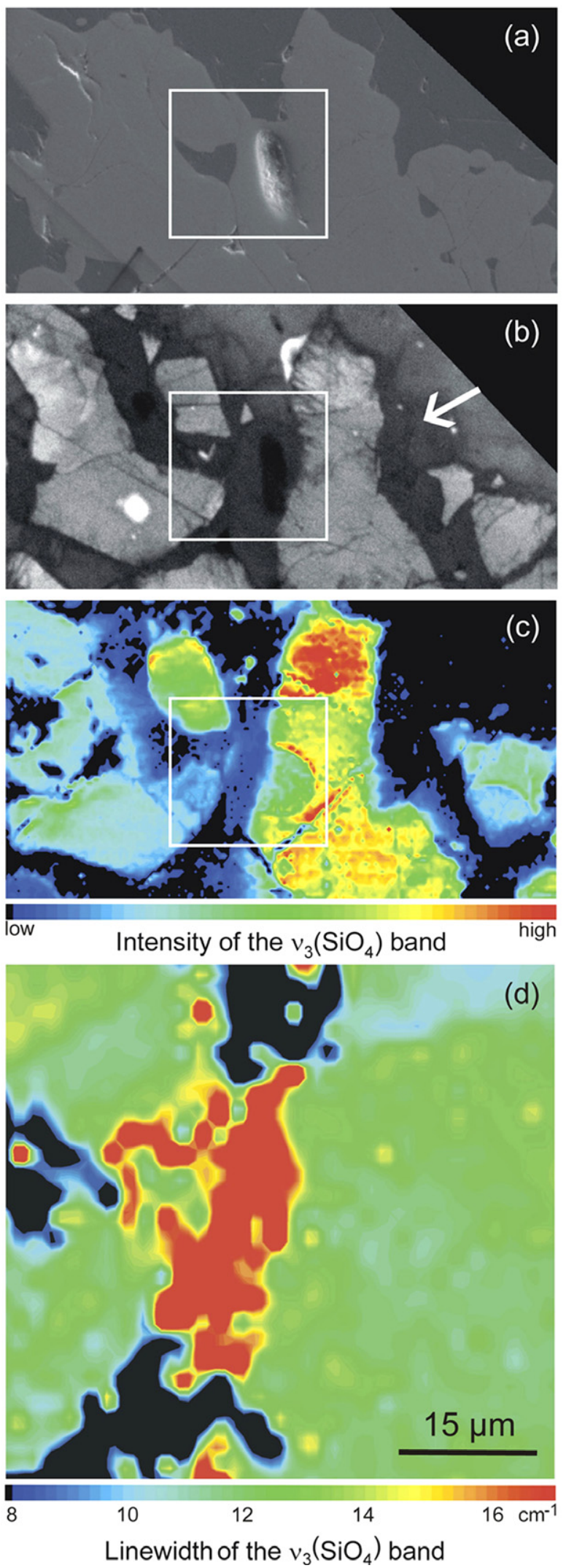

Fig. 8. (a) SE image of a part of the zircon aggregate. (b) CL image of the same area shown in (a). (c) Map of the Raman intensity of the antisymmetric stretching band of the $\mathrm{SiO}_{4}$ tetrahedra for the same part of the zircon aggregate shown in (a) and (b). (d) Map of the Raman band width within the square shown in $(\mathrm{a}-\mathrm{c})$. fitting procedure used to create the map is suspected of combining the $v_{1}$ and $v_{3}$ bands in some cases where intensity was very low and we have attempted to confirm the matrix data by making individual Raman measurements. These show that some areas in the matrix zircon have widths as low as $12 \mathrm{~cm}^{-1}$, and most measurements fall in the range between 12 and $17 \mathrm{~cm}^{-1}$. The band widths of the matrix zircon are thus not consistently larger than those of the primary zircon with similar $\alpha$-doses, although the Raman intensity of the matrix zircon is significantly lower than the primary zircon. Whereas intensity variations between different fragments of primary zircon partly reflect differences in crystallographic orientation with respect to the polarisation of the laser beam (compare the $v_{1}$ and $v_{3}\left(\mathrm{SiO}_{4}\right)$ band intensity ratios of spectra $\mathrm{A}$ and $\mathrm{B}$ shown in Fig. 6 with the intensity ratios of fragments in Fig. 8c) and thus support the conclusion that the fragments are rotated against each other, the lower intensity of the matrix zircon must reflect differences in the scattering volume of crystalline material (compare band intensity ratios of spectra $\mathrm{B}$ and $\mathrm{C}$ shown in Fig. 6 and the intensity pattern in Fig. 8c). This implies that the number of crystalline domains in the secondary matrix zircon is lower, although their degree of disorder seems to be similar to that of the high $\mathrm{U}(\mathrm{Th})$ areas of the primary zircon, as indicated by their similar band width.

\section{Formation of the aggregate}

On the basis of the above evidence we are in a position to consider possible processes and their timing that could have produced the observed zircon aggregate. On first examination the aggregate of irregular shaped zircons resembles to some degree clusters of small zircon crystals formed in hydrothermal systems along a fracture or weakness in a metamorphic rock. However the highly irregular shapes of the individual grains together with the irregular pattern of segmented zoning which cannot be traced from one grain to the next demonstrates convincingly that individual grains are displaced fragments of possibly one large primary grain, rather than a cluster of individual crystals.

The pattern of zoning observed in the CL images does not resemble igneous oscillatory zoning commonly found in terrestrial zircons or sector and fir tree zoning reported in zircon from high grade metamorphic rocks (e.g., Vavra et al., 1996). Each large fragment is composed of a few distinct sectors each of which has a consistent but different $U$ and Th content. However, only disrupted remnants of the zones are present in individual fragments and the complete zoning pattern of the original zircon crystal is not known. Our present interpretation is that the pattern of sector zoning represents the internal structure of the primary zircon, grown under equilibrium conditions in a dry melt. Assuming the plagioclase dominated clast represents the parent rock the zircon probably crystallised from a mafic (anorthositic) magma, possibly a late differentiate from the cooling lunar magma ocean. 
Nothing like the present zircon aggregate has been reported from terrestrial impact sites. The closest terrestrial analogy to the aggregate known to the authors is the description by Rimsa et al. (2004) of brittlely fractured zircons from a strongly deformed, migmatised, Sveconorwegian granite. The zircons are composed of numerous angular zircons fragments separated by a network of fractures filled with zircon "cement". The primary sector zoned zircon has a nearly concordant age of ca. $1.310 \mathrm{Ga}$, whereas the vein zircon is essentially concordant at ca. $0.900 \mathrm{Ga}$. These authors explain the texture as forming during brittle deformation by hydrothermal precipitation of zircon into the fractures without any rotation displacement of the fragmented zircon, as is evident by a continuous pattern of zones across the zircon filled fractures. This vein zircon has a very low Th content indicating the insolubility of Th in the migrating fluids. Such a replacement mechanism involving hydrothermal processes is of course untenable for the anhydrous lunar environment. However, the $\mathrm{U}-\mathrm{Pb}$ age difference, from 4.31 to $4.18 \mathrm{Ga}$, between the primary and secondary zircon and the textural similarity between the occurrences could be explained by proposing that the pomegranate zircon aggregate formed by compound, shock-fracturing of the primary zircon grain at 4.18 followed immediately by injection of new zircon into the fractures with a coincidental shuffling of the shattered primary zircon fragments. A mechanism similar to that proposed by Neal and Taylor (1991) may be envisaged, where zircon, complexly fractured in response to a remote impact at $4.18 \mathrm{Ga}$, was impregnated with new zircon precipitated from percolating low viscosity, basic, immiscible melt, derived from urKREEP, Such a model provides an explanation for the lack of obvious shock effects in the matrix zircon and the fragments, the younger $\mathrm{U}-\mathrm{Pb}$ age of the matrix and the variation in the $\mathrm{Th} / \mathrm{U}$ ratio between matrix and fragments. However, this model does not provide a satisfactory explanation for the lensoid deformation of the aggregate and the pseudotachylite-like structure, with a zircon matrix that contains a myriad of fine fragments of primary zircon as determined from the Raman measurements and birefringent image. An alternative explanation is that the observed zircon aggregate is entirely the result of a major shock event. According to Reimold (1995) pseudotachylite in impact structures can be generated by shock/ brecciation melting and by friction melting or both. The possibility that, under extreme shock, fragmentation and distortion of the zircon was accompanied by shock/friction melting at grain boundaries resulting in the observed apparent fracture filled structure, is not likely as at extreme temperatures zircon would be expected to decompose rather than melt and there is no indication of dissociation of zircon into $\mathrm{ZrO}_{2}$ and $\mathrm{SiO}_{2}$ (e.g., Mursic et al., 1992). Alternatively the observed pseudotachylitic structure could result from a shock conversion of zircon to a new phase or even an amorphous state (Gucsik et al., 2002) although as described earlier there is no evidence that the matrix zircon has a reidite structure (Knittle and Williams, 1993) or is amorphous. However, under high shock pressures of 35 $45 \mathrm{GPa}$ the transfer of energy into a quartz or feldspar crystal can result in the conversion of the crystal structure partly or entirely to phase referred to as diaplectic glass by French (1998) and thetomorphic glass by Chao (1967). Diaplectic glasses do not melt or flow but preserve the texture of the mineral and retain much of the ordered atomic structure of the original crystal (Bunch et al., 1967; Arndt et al., 1982; Stöffler, 1984). Also, there is no chemical exchange between the glass and other phases (Chao, 1967). One problem in proposing a diaplectic glass model for the present zircon aggregate is the question of why a fine network of zircon was converted to glass whereas enclosed angular fragments were left with almost no evidence of shock. This question is answered to some extent by the report by French (1998) that shocked plagioclase can be partially converted to isotropic diaplectic feldspar glass (maskelynite), whereas the rest of the plagioclase grain remains crystalline. It is shown in French (1998, Fig. 4.31) that the boundary between the amorphous and crystalline state within the plagioclase is irregular but generally sharp and somewhat similar to the observed boundary between the primary and secondary zircon in the present aggregate. The conditions under which extreme shock can reduce the zircon structure to an amorphous state have been determined experimentally by Gucsik et al. (2002) who reported that after experimental shock pressures of $60 \mathrm{GPa}$ the Raman spectrum showed no zircon bands indicating that it was amorphous. However, our present Raman measurements show that the matrix zircon retains some original structure, which is in accord with the comment by French (1998, p. 55) that diaplectic glasses retain much of the ordered atomic structure of the original crystal. It is envisaged that crushing and extension of the original zircon to its present elongate pseudotachylitic form involved the development of a diaplectic glass matrix in areas of pressure release from the combined result of shock fracturing and friction heating. This provides a better explanation than the "injection of new zircon model" for the presence of numerous small angular primary fragments in the matrix zircon. Extreme shock is accompanied by a post-shock thermal pulse and it is shown in French (1998, Fig. 4.1) that a post-shock temperature pulse of about 500$1000{ }^{\circ} \mathrm{C}$ would accompany a $25-40 \mathrm{GPa}$ shock and that higher temperatures would be generated by more extreme shock. This instantaneous temperature pulse could volatilise $\mathrm{Pb}$ from shock formed diaplectic zircon. The addition of $\mathrm{U}$ to the diaplectic zircon glass could also be in response to the extreme thermal shock. It is possible that the high $\mathrm{U}$ could be from a decomposed U-rich part of the primary zircon which selectively responded to the shock, but this would require the corresponding Th to be lost from the system. Alternatively U could have been added by an external metasomatic process. One suggestion is that these elements were incorporated into the open structure of the diaplectic zircon glass as a result of a migrating front of incompatible trace elements which included $\mathrm{U}$ but not $\mathrm{Th}$, possibly 
produced by progressive zone refining associated with a declining temperature gradient and shock pressure radiating from a maximum at the point of impact. This could explain the apparent inhomogeneous concentration of $\mathrm{U}$ in the matrix zircon by proposing that $\mathrm{U}$ penetration into the diaplectic zircon was variable and generally highest towards the outer margin of the aggregate. Taking into account all the evidence we presently favour a model where an original zircon in a host anorthositic rock was shattered and compressed to an aggregate of surviving primary fragments in a matrix of finely crushed (to submicron size) and diapletic zircon, probably in the parauthochtonous rocks beneath the floor of a major impact event at $4.18 \mathrm{Ga}$.

Aphanetic melt breccia 73235 has been interpreted as a melt product of the Serenitatus basin impact (Dence et al., 1976; Wolf, 1981) although Spudis and Ryder (1981) argue that the Apollo 17 melts display much greater compositional diversity that would a single impact melt sheet and favour generation of the diverse melt rocks by multiple impacts. Nevertheless, the consistency of ${ }^{40} \mathrm{Ar} /{ }^{39} \mathrm{Ar}$ ages of ca. 3.9-4.0 Ga for the Apollo 17 melt breccias including 73235 (Kirsten and Horn, 1974; Turner and Cadogan, 1975; Jessberger et al., 1977) demonstrates a thermal event at this time, attributed to the Serenitatus impact, that outgassed the Apollo 17 impact melts and many of their clasts. This thermal event has had no detectable effect on the $\mathrm{U}-\mathrm{Pb}$ system of the present zircon aggregate.

\section{Summary and conclusions}

Our present SHRIMP U-Pb analyses confirm those of Smith et al. (1986) that the pomegranate zircon registers two ages, 4.31 and $4.18 \mathrm{Ga}$. We also agree with these authors that the $4.31 \mathrm{Ga}$ ages are restricted to the zircon crystal fragments and the $4.18 \mathrm{Ga}$ ages to the surrounding zircon matrix, referred to as an overgrowth by Smith et al. (1986). However, it is evident from the CL imagery that the complex zircon aggregate consists of a multitude of broken and displaced zircon fragments set within a featureless, dark-CL matrix which is itself zircon. The presence of residual sector zoning in the larger of the broken fragments, the consistent $\mathrm{U} / \mathrm{Th}$ ratio and $\mathrm{U}$ content of individual sectors and the uniform age of $4.31 \mathrm{Ga}$ for all measured fragments are taken as strong evidence that the fragments were once a single large zircon that crystallised in KREEP rich melt. Whereas the nature of the matrix zircon is still not completely resolved it is suggested that under extreme friction/heating during shock compression and distortion, matrix zircon was milled to a mass of sub-micron and amorphous particles producing the present pseudotachylite-like structure and resulting in the loss of radiogenic $\mathrm{Pb}$ and the gain of $\mathrm{U}$ from an unknown external source. In terms of the geological history of the Moon the intense shock recorded by the zircon at $4.18 \mathrm{Ga}$ dates a significant lunar impacting event. Rounding of the host anorthositic clast, including one exposed surface of the zircon aggregate, reflects severe mechanical and thermal abrasion during transport and settling of unsorted surge material to form the clast rich aphanitic melt breccia 73235, possibly during the Serenitatis impact. Whereas the temperature pulse associated with this event caused degassing of $\mathrm{Ar}$ and mixing of the $\mathrm{Rb}-\mathrm{Sr}$ systems, resulting in a strong age signature at ca 3.9$4.0 \mathrm{Ga}$, it was insufficient to disturb the zircon $\mathrm{U}-\mathrm{Pb}$ system which has no record of this event.

\section{Acknowledgments}

We thank Dr. Martin Whitehouse, Dr. Fernando Corfu, Dr. John Hanchar and an anonymous reviewer for very constructive reviews of the manuscript. We thank Frank Tomaschek for kindly providing a synthetic zircon for Raman measurement. This research was supported by a grant to RTP and AAN from the Australian Research Council, The lunar sample was provided by NASA.

Associate editor: Yuri Amelin

\section{References}

Arndt, J., Hummel, W., Gonzalez-Cabeza, I., 1982. Diaplectic labradorite glass from the Manicouagan impact structure. I. Physical properties, crystallization, structural and genetic implications. Phys. Chem. Mineral. 8, 230-239.

Bunch, T.E., Cohen, A.J., Dence, M.T., 1967. Natural terrestrial maskelynite. Amer. Mineral. 52, 244-253.

Chao, E.C.T., 1967. Impact metamorphism. In: Abelson, P.H. (Ed.), Researches in Geochemistry, vol. 2. John Wiley and Sons, New York, USA, pp. 204-233.

Compston, W., Williams, I.S., Meyer, C., 1984. U-Pb geochronology of zircons from the lunar breccia 73217 using a sensitive high-resolution ion microprobe. Proceedings of Lunar and Planetary Science Conference XIV, J. Geophys. Res. 89, B525-B534.

Compston, W., Williams, I.S., Meyer, C., 1991. Initial Pb isotopic compositons of lunar granites as determined by ion microprobe. In: Taylor, H.P. Jr., O’Neil, J.R., Kaplan, I.R. (Eds.), Stable Isotope Geochemistry: A Tribute to Samuel Epstein. Geochem. Soc. Special Pub. No. 3, 472- 486 .

De Laeter, J.R., Kennedy, A.K., 1998. A double focussing mass spectrometer for geochronology. Int. J. Mass Spectrom. Ion Process 178, 43-50.

Dence, M.R., Grieve, A.F., Plant, A.G., 1976. Apollo 17 grey breccias and crustal composition in the Serenitatis Basin region. Proceedings of Lunar Science Conference VII, 1821-1832.

French, B.M., 1998. Traces of Catastrophe: A Handbook of ShockMetamorphic Effects in Terrestrial Meteorite Impact Structures. LPI Contribution No. 954, Lunar and Planetary Institute, Houston, USA, p. 120 .

Gucsik, A., Koeberl, C., Brandstätter, F., Reimold, W.U., Libowitzky, E., 2002. Cathodoluminescence, electron microscopy, and Raman spectroscopy of experimentally shock-metamorphosed zircon. Earth Planet. Sci. Lett. 202, 495-509.

Hodges, F.N.; Kushiro, I., 1974. Apollo 17 petrology and experimental differentiation sequences in model Moon compositions. Proc. Fifth Lunar Sci. Conf., Geochim. Cosmochim. Acta (Suppl. 5), 505-520.

Ireland, T., Wlozka, F., 1992. The oldest zircons in the solar system. Earth Planet. Sci. Lett. 109, 1-10.

JJessberger, E.K., Kirsten, T., Staudacher, Th., 1977. One rock and many ages-Further $\mathrm{K}$-Ar data on consortium breccia 73215. Proc. Eighth Lunar Sci. Conf., Geochim. Cosmochim. Acta (Suppl. 8), 2567-2580. 
Kennedy, A.K., de Laeter, J.R., 1994. The performance characteristics of the WA SHRIMP II ion microprobe. In: Eighth International Conference on Geochronology, Cosmochronology and Isotope Geology. Berkeley, USA. Abstracts Vol., U.S. Geological Survey Circular, 1107, 166.

Kirsten, T., Horn, P., 1974. Chronology of the Taurus-Littrow region III: Ages of mare basalts and highland breccias and some remarks about the interpretation of lunar highland rock ages. Proc. fifth Lunar Sci. Conf. Supplement 5, Geochim. Cosmochim. Acta 2 (Suppl. 5), 1451-1475.

Knittle, E., Williams, Q., 1993. High-pressure Raman Spectroscopy of $\mathrm{ZrSiO}_{4}$ : observation of the zircon to scheelite transition at $300 \mathrm{~K}$. Amer. Mineral. 78, 245-252.

Meyer, C., Williams, I.S., Compston, W., 1996. Uranium-lead ages for lunar zircons: Evidence for a prolonged period of granophyre formation from 4.32 to $3.88 \mathrm{Ga}$. Meteorit. Planet. Sci. 31, 370-387.

Mursic, Z., Vogt, T., Frey, F., 1992. High-temperature neutron powder diffraction study of $\mathrm{ZrSiO}_{4}$ up to $1900 \mathrm{~K}$. Acta Crystallogr. B48, 584-590.

Nasdala, L., Irmer, G., Wolf, D., 1995. The degree of metamictization in zircon: a Raman spectroscopic study. Eur. J. Mineral. 7, 471-478.

Neal, C.R., Taylor, L.A., 1991. Evidence for metasomatism of the lunar highlands and the origin of whitlockite. Geochim. Cosmochim. Acta 55, 2965-2980.

Nelson, D.R., 1997. Compilation of SHRIMP U-Pb zircon geochronology data, Record 1997/2. Geological Survey of Western, Australia, Perth, Australia, p. 189.

Nyquist, L.E., Bansal, B.M., Wiseman, H., Jahn, B.M., 1974. TaurusLittrow chronology: some constraints on early lunar crustal development. Proc. Fifth Lunar Sci. Conf., Geochim. Cosmochim. Acta 2 (Suppl. 5), $1515-1539$

Pidgeon, R.T., Furfaro, D., Kennedy, A.K., Nemchin, A.A., van Bronswjk, W., 1994. Calibration of zircon standards for the Curtin SHRIMP II. In: Eighth International Conference on Geochronology, Cosmochronology and Isotope Geology. Berkeley, USA. Abstracts Vol., U.S. Geological Survey Circular, 1107, p. 251.

Pidgeon, R.T., Nemchin, A.A., Meyer, C., 2005. A further investigation of the exceptional zircon aggregate in lunar thin section 73235,83 (abs\#1275) Lunar and Planetary Science Conference XXXVI.

Pidgeon, R.T., Nemchin, A.A., Meyer, C., 2006. Complex histories of two lunar zircons as evidenced by their internal structures and $\mathrm{U}-\mathrm{Pb}$ ages. (abs\#1548) Lunar Planetary Science Conference XXXVII.

Reimold, W.U., 1995. Pseudotachylite in impact structures-generation by friction melting and shock brecciation?: A review and discussion. Earth Sci. Rev. 39, 247-265.

Rhodes, J.M., Rogers, K.V., Shih, C.-Y., Bansal, B.M., Nyquist, L.E., Wiesmann, H., Hubbard, N.J., 1974. The relationship between geology and soil chemistry at the Apollo landing site Proc. Fifth Lunar Sci. Conf., Geochim. Cosmochim. Acta (Suppl. 5), 1097-1117.

Rimsa, A., Johansson, L., Whitehouse, M.J., 2004. Zircon fracturing, healing and rim formation: Chronology of the metamorphic process? Abstracts of the 13th Goldschmidt Conference, Copenhagen, June 5-11, 2004. Geochim. Cosmochim. Acta, 68/11s, A185.
Ryder, G., 1993. Catalog of Apollo 17 rocks. vol. 1, National Aeronautics and Space Administration, Lyndon B. Johnson Space Center Houston USA. JSC \#26088, pp. 410.

Schonfeld, E., Myer, C., 1972. The abundance of components of the lunar soils by a least squares mixing model and the formation age of KREEP. Proc. Third Lunar Sci. Conf., Geochim. Cosmochim. Acta 2 (Suppl. 3), 1397-1420.

Smith, J.M., Meyer, C., Compston, W., Williams, I.S., 1986. 73235,82 (pomegranate): An assemblage of lunar zircon with unique overgrowth. In: Proceedings of Lunar Planetary Science Conference $X V I I$, Lunar and Planetary Institute, Houston, USA, pp. 805 806.

Spudis, P.D., Ryder, G., 1981. Apollo 17 impact melts and their relation to the Serenitatis basin. In: Schultz, P.H., Merrill, R.B. (Eds.), Multiring basins: Formation and evolution; Proceedings of Lunar and Planetary Science Conference, XIIA, Lunar and Planetary Institute Houston, USA, pp. 133-148.

Steiger, R., Jäger, E., 1977. Subcommission on Geocheonology: convention on the use of decay constants in geo- and cosmochronology. Earth Planet. Sci. Lett. 36, 359-362.

Stöffler, D., 1984. Glasses formed by hypervelocity impact. J. Non-cryst. Solids 67, 465-502.

Tanabe, K., Hiraishi, J., 1980. Correction of finite slit width effects on Raman line widths. Spectrochim. Acta 36, 341-344.

Turner, G., Cadogan, P.H., 1975. The history of lunar bombardment inferred from ${ }^{40} \mathrm{Ar}-{ }^{39} \mathrm{Ar}$ dating of highland rocks. In: Proceedings of Lunar Science Conference VI, Lunar and Planetary Institute, Houston, USA, pp. $1509-1538$.

Van Westrenen, W., Frank, M.R., Hanchar, J.M., Fei, Y-W., Finch, R.J., Zha, C-S., 2004. In situ determination of the compressibility of synthetic pure zircon $\left(\mathrm{ZrSiO}_{4}\right)$ and the onset of the zircon-reidite phase transition. Amer. Mineral. 89, 197-203.

Van Westrenen, W., Frank, M.R., Fei, Y-W., Hanchar, J.M., Finch, R.J., Zha, C-S., 2005. Compressibility and phase transition kinetics of lanthanide-doped zircon. J. Am. Ceram. Soc. 88, 1345-1348.

Vavra, G., Gebauer, D., Schmid, R., Compston, W., 1996. Multiple zircon growth and recrystallisation during polyphase Late Carboniferous to Triassic metamorphism in granulites of the Ivrea Zone (Southern Alps): an ion microprobe (SHRIMP) study. Contrib. Mineral. Petrol. 122, 337-368.

Williams, I.S., 1988. U-Th-Pb Geochronology by Ion Microprobe. In: McKibben, M.A., Shanks, III, W.C., Riley, W.I. (Eds). Applications of microanalytical techniques to understanding mineralising processes. Reviews in Economic Geology, 7, 1-35.

Wittmann, A., Kenkmann, T., Schmitt, R.T., Stöffler, D., 2006. Shockmetamorphosed zircon in terrestrial impact craters. Meteorit. Planet. Sci. 41, 433-454.

Wolf, E.W. and others., 1981. The geologic investigation of the TaurusLittros Valley: Apollo 17 landing site. US Geol Survey Prof. Paper, 1080, p. 280. 